\title{
Household pets as a potential reservoir for Clostridium difficile infection
}

\author{
SP BORRIELLO, PAULINE HONOUR, T TURNER,* FIONA BARCLAY \\ From the Clinical Research Centre, Watford Road, Harrow, Middlesex, and the *Mandeville Veterinary Hospital, \\ Middlesex.
}

SUMMARY The purpose of this study was to assess the carriage of Clostridium difficile by household pets tom determine their potential as a reservoir of infection. The selective cycloserine-cefoxitin medium was used for $C$ difficile isolation, and tissue culture used for detection of cytotoxin.

Carriage of $C$ difficile by household pets was found to be common (23\%). The carriage tends to be transient and does not appear to be associated with gastrointestinal disease. Although carriage was higher in animals who had antecedent antibiotic treatment $(31 \%)$ compared to those which had not (19\%), the differences were not statistically significant. In most cases non-cytotoxigenic strains were isolated. Of then cytotoxigenic strains isolated at least one strain was pathogenic in a well documented animal model of human disease. Both cytotoxigenic and non-cytotoxigenic strains of $C$ difficile could be isolated from the $\vec{\infty}$ environment of the animals studied.

Evidence collected over the last four years firmly implicates Clostridium difficile as a cause of both non-antibiotic and antibiotic associated pseudomembranous colitis (PMC). ${ }^{12}$ Recent evidence also indicates that this organism may play an aetiological role in diarrhoea ${ }^{13-5}$ and exacerbation of inflammatory bowel disease. ${ }^{67}$ Before the aetiology of PMC was delineated the unusual geographical and temporal clustering of cases implied that an infectious agent was responsible. ${ }^{810}$ In addition, the different carriage rates of this organism noted in infants with different types of $C$ difficile predominating in a given centre-that is, cytotoxigenic or non-cytotoxigenic, and colonisation of infants even if delivered by caesarean section imply that the organism can be acquired from the environment ${ }^{11-14}$ and that cross-infection may take place. Recent work has demonstrated that cross-infection probably does take place among hospitalised patients ${ }^{1516}$ and that the organism can be isolated from the environment of patients who have been excreting $C$ difficile. ${ }^{17-19}$ Evidence indicates that in the majority of cases of $C$ difficile-mediated disease the organism is acquired from the environment by a host susceptible to infection. This need not necessarily be only in hospitalised patients as cases of $C$ difficile-associated diarrhoea ${ }^{3420}$ and $P C^{21}$ (and Borriello SP, unpublished observations, 1979) have

Accepted for publication 4 August 1982 been noted in the community. We investigated the furthe possibility that household pets may act as a reservoir of $\frac{0}{8}$ difficile and may, therefore, contribute to the contamina 2 tion of their environment with $C$ difficile spores.

\section{Material and methods}

SOURCE OF SPECIMENS

Of the samples analysed the majority were forwarded from a local veterinary hospital (49 dogs, 19 cats, one duck). The remainder were made available by colleaguesi

SPECIMEN COLLECTION

Faecal specimens were collected either by charcoal swa or by collection of about $0.5 \mathrm{~g}$ of stool either immediatel after void or during operation. Samples were analyse within 24 hours of collection.

ISOLATION OF C DIFFICILE

Isolation was performed by the use of both a selective medium and the use of alcohol to select for clostridia spores as previously described. ${ }^{22}$ All selective media contained $0 \cdot 1 \%(\mathrm{wt} / \mathrm{vol})$ sodium taurocholate. ${ }^{23}$

ENVIRONMENTAL SAMPLING

Contact plates (Nunc Gibco Biocult contact Petri dish Gibco Europe Ltd, Paisley, Scotland) containing th\&्ष selective medium described above were used to isolate difficile from various surfaces. 


\section{DETECTION OF CYTOTOXIN}

Cytotoxin was detected as described previously. ${ }^{24}$ The "tube method" was used. Stool samples were analysed for the presence of a cytotoxin that was neutralised by the cross-reacting $C$ sordellii antitoxin. Isolates of $C$ difficile were analysed for the in vitro production of this toxin. They were grown in Robertson's cooked meat medium (Southern Group) for three days. Neat cell free filtrates $(0.45 \mu \mathrm{m}$ filters) were then tested for the presence of cytotoxin. Any cytopathic effect that could be neutralised by $C$ sordellii antitoxin was recorded. Absence of any effect on the cells was taken to indicate that the isolates did not produce cytotoxin.

\section{TEST FOR PATHOGENICITY}

Four strains of $C$ difficile were each tested for their ability to induce a fatal ileocaecitis in three antibiotic-treated hamsters. Male Syrian hamsters (Mesocricetus auratus) were given $0.5 \mathrm{mg}$ of clindamycin phosphate (Dalacin ${ }^{\mathrm{R}} \mathrm{C}$ phosphate; Upjohn, Crawley, West Sussex, England; supplied as 4-ml ampoules for clinical use) interperitoneally as a single $0.5 \mathrm{ml}$ injection. The animals were then housed in single isolator cages with sterile bedding, water and food. ${ }^{25}$ After five days the hamsters were challenged with an oral dose of $0.5 \mathrm{ml}$ of a washed suspension of $C$ difficile containing between $10^{7}$ and $10^{8}$ organisms $/ \mathrm{ml}$. The animals were returned to their sterile environments and observed daily. At the end of nine days any surviving animal was challenged with a pathogenic strain of $C$ difficile isolated from a hamster (strain 2B) to confirm that the animal was still susceptible to $C$ difficile. In this way survival could be attributed to a lack of pathogenicity by the original isolate as opposed to resistance to infection by recolonisation by a normal gut flora due to accidental contamination during handling.

\section{Results}

The animals studied are presented in Table 1. Eleven dogs, six cats, a duck and a goose were shown to carry $C$ difficile. Only eight of these animals were known to have recently received antibiotics (Table 2 ). In most cases the animals harboured non-cytotoxigenic strains (Table 2). However, cytotoxigenic strains were isolated from a dog, a goose, a duck and three cats (Table 2). Only four of these animals were known to have recently received antibiotics. Of the samples forwarded from the local veterinary hospital two cats and a duck excreted cytotoxigenic strains. The other positive animals harboured noncytotoxigenic strains. It was possible to resample from five of the positive and 19 of the negative animals between four and six weeks after the primary investigation. None of the positive animals continued to carry $C$ difficile even though two of these animals had received antibiotics during the intervening period (clamoxacillin and trimethoprim/sulphadiazine). Of the 19 negative animals
Table 1 Carriage of $C$ difficile in household pets

\begin{tabular}{lcl}
\hline Animal & No harbouring C difficile & $\begin{array}{l}\text { Percentage } \\
\text { carriage }\end{array}$ \\
\hline Dogs(52) & 11 & 21 \\
Cats (20) & 6 & 30 \\
Avian*(6) & 2 & 33 \\
Other† (4) & 0 & 0 \\
Total (82) & 19 & 23 \\
\hline *Ducks(2), geese (2), chicken (1), ring-necked parakeet (1). \\
+Rabbit (1), goat (1), hedgehog (1), guinea pig(1).
\end{tabular}

Table 2 Antibiotics and cytotoxin associated with C difficile positive samples

\begin{tabular}{lll}
\hline $\begin{array}{l}\text { Stool } \\
\text { cytotoxin }\end{array}$ & $\begin{array}{l}\text { Cytotoxin status } \\
\text { of isolate }\end{array}$ & Animal (antibiotic) \\
\hline ND & + & Goose (none), cat (none) \\
+ & + & Cat (yes, but unknown) \\
+ & - & Dog (clamoxacillin), cat (lincomycin) \\
- & + & Duck (oxytetracyclin), \\
& - & dog (lincomycin), cat (chloramphenicol) \\
- & - & dogs (none), dog (clindamycin) \\
& &
\end{tabular}

$\mathrm{ND}=$ not done

retested two were found to be positive for $C$ difficile. In both cases the strains isolated were non-cytotoxigenic. Neither animal had received antibiotics during the intervening period.

Of the 82 animals investigated 53 had not received antibiotics up to 12 weeks prior to sampling. All of the other 29 animals had received recent antibiotic treatment: Comparisen of the animals, when considered as two groups on the basis of presence or absence of recent antibiotic treatment demonstrated that there was a higher carriage rate of $C$ difficile/toxin in the group that had recently received antibiotics than in the "non-antibiotic" group with figures of $31 \%$ and $19 \%$ respectively. However, when analysed by the $\chi^{2}$ test the differences were not statistically significant.

Reliable ages were available for the cats and dogs studied. The mean age of the positive animals was $5.8 \mathrm{yr}$ (range 4 months to $15 \mathrm{yr}$ ), and that of the negative animals $6.7 \mathrm{yr}$ (range 2 months to $15 \mathrm{yr}$ ). Four of eight $(50 \%)$ of those younger than $1 \mathrm{yr}$ and $12 / 60(20 \%)$ of those older than 1 yr were positive for $C$ difficile. The difference in these results was not statistically significant by the $\chi^{2}$ test, although it approached significance at the $5 \%$ level by Fisher's exact test.

Of the four strains of $C$ difficile tested for pathogenicity in the hamster model of antibiotic-associated ileocaecitis two strains were positive (Table 3). In two cases the organism failed to colonise the hamsters. Both of these strains were isolated from dogs. In those cases where colonisation did not take place the animals died after subsequent challenge with the known pathogenic strain of $C$ difficile. The surviving animals in which the noncytotoxigenic strains had established survived subsequent challenge with the pathogenic strain. This apparent 
Table 3 Pathogenicity of animal isolates of $C$ difficile in the hamster model of antibiotic-associated ileocaecitis

\begin{tabular}{llll}
\hline Animal source & $\begin{array}{l}\text { Cytotoxigenic status } \\
\text { ofC difficile }\end{array}$ & $\begin{array}{l}\text { Establishment } \\
\text { in hamster }\end{array}$ & $\begin{array}{l}\text { Lethal to } \\
\text { hamster }\end{array}$ \\
\hline Dog & - & $2 / 3$ & - \\
Dog & - & $2 / 3$ & - \\
Duck & + & + & $2 / 3$ \\
Cat & + & + & $3 / 3$ \\
\hline
\end{tabular}

protection by prior colonisation with non-cytotoxigenic strains of $C$ difficile has been noted previously with human source isolates (Borriello SP, Barclay F, unpublished observations, 1982).

The results of environmental sampling show that of the 35 sites investigated at the veterinary hospital, four yielded $C$ difficile. These sites were a kennel room cupboard, a mop, and the surface of a washing machine. In three of these cases the isolate recovered produced cytotoxin in vitro. The non-cytotoxigenic strain was isolated from the sole of one of the investigators shoes. Sampling around the home environment of one of the dogs excreting $C$ difficile failed to yield $C$ difficile from the six sites investigated. Areas investigated were the animal feeding bowls and bed and the living room and bedroom carpets. Sampling of the seats of the car in which the animal was frequently transported also failed to yield this organism.

\section{Discussion}

There have only been a few reported isolations of $C$ difficile from animals. These include isolations from camel, cow, donkey and horse dung, ${ }^{26,} 27$ the intestinal contents of the antarctic Weddell seal, ${ }^{28}$ as part of the normal flora of conventional neonatal hares, ${ }^{29}$ and the isolation of a cytotoxigenic strain from a sitatunga deer (Grant IK, Borriello SP and Honour P, unpublished observations, 1982). There were no reports of carriage of $C$ difficile in household pets and therefore the potential for disease in these types of animals, and for the transmission of the organism from animal to man either directly or via a fomite was unknown. The results of this study clearly demonstrate that household pets can harbour $C$ difficile, and further, that this organism can be isolated from their immediate environment. Unlike the situation with human adults, $C$ difficile carriage in these animals does not appear to be associated with recent antibiotic therapy, although one must accept that the study group being considered is small and composed of a number of different species of different ages. In addition, none of the positive animals had bowel motions atypical for the species, even though in some cases cytotoxin was present in the faeces. In these respects, carriage in household pets is similar to that of human infants, even though only four of the positive animals were less than 12 months old at the time of sampling.
Borriello, Pauline Honour, Turner, Fiona Barclay

In two cases animal isolates were shown to be able t㞔 induce a fatal enterocaecitis in the hamster model of antibiotic-associated ileocaecitis. In view of this, it is interesting to speculate that household pets may act as $\frac{0}{0}$ source of infection and subsequent disease for people io the community, such as those receiving antibiotic therapy There is as yet no documented case of animal-to-persol transmission of $C$ difficile and even in view of the awareness that household pets can harbour this organismen in the absence of a satisfactory biotyping scheme this possibility will remain speculative. However, we have experience of community cases of $C$ difficile-associated pseudomembranous colitis, and of three cases of relapse after vancomycin therapy for $C$ difficile infection thap have occurred while the patient has been at home ${ }_{\text {o }}^{\omega}$ Although it is possible that relapse is due to outgrowth of spores remaining in the gastrointestinal tract, ${ }^{30}$ reinfeco tion is also a possibility. In view of our findings, we conclude that in future the possibility of infection from a household pet should be considered and investigated.

SP Borriello wishes to acknowledge the support Upjohn Ltd.

\section{References}

1 Borriello SP, Larson HE. Antibiotic and pseudomembranous colitio J Antimicrob Chemother. 1981;7, suppl A:53-62.

2 Bartlett JG, Chang TW, Gurwith M, Gorbach SL, Onderdonk AB Antibiotic associated pseudomembranous colitis due to toxin producing clostridia. N Engl J Med 1978;298:531-4.

3 Gilligan PH, McCarthy LR, Genta VM. Relative frequency of Clostridium difficile in patients with diarrhoeal disease. $J \mathrm{Cl} \overrightarrow{\overline{\mathrm{B}}}$ Microbiol 1981;14:26-31.

4 Brettle RP, Poxton IR, Murdoch J McC. Brown R. Byrne MD, Colleg JG. Clostridium difficile in association with sporadic diarrhoe Br Med J 1982;284:230-2.

5 Jewkes J, Larson HE, Price AB, Sanderson PJ, Davies HA. Aetiolog of acute diarrhoea in adults. Gut 1981;22:388-92.

6 Trnka YM, LaMont JT. Association of Clostridium difficile toxin wiדి symptomatic relapse of chronic inflammatory bowel disease. Gastroenterology 1981;80:693-6.

7 Bolton RP, Sherriff RJ, Read AE. Clostridium difficile associate diarrhoea: a role in inflammatory bowel disease? Lancet 1980; $\bar{\tau}$. 383-4.

8 Kabins A, Spira JJ. Outbreak of clindamycin-associated colitis. Ann Intern Med 1975;83:830-1.

${ }^{9}$ Swartzberg JE, Maresca RM, Remington JS. Gastrointestinal side: effects associated with clindamycin. ArchInternMed 1976;136:876- ov

10 Miller RR, Jick H. Antibiotic-associated colitis. Clin Pharmacol Ther 1977;22:1-6.

11 Borriello SP. Clostridium difficile and its toxin in the gastrointestina tract in health and disease. Res Clin Forums 1979;1:33-5.

12 Viscidi R, Willey S, Bartlett JG. Isolation rates and toxigenic potenti⿺廴⿻肀二𠃋 of Clostridium difficile isolation from various patient populations Gastroenterology 1981;81:5-9.

13 Smith MF, Borriello SP, Claydon GS, Casewell MW. Clinical and bacteriological findings in necrotising enterocolitis: a controlled study. J Infect 1980;2:23-31.

14 Shuttleworth R, Taylor M, Jones DM. Antimicrobial susceptibilities Clostridium difficile. J Clin Pathol 1980;33:1002-5.

15 Rogers TR, Petrou M, Lucas C, et al. Spread of Clostridium difficiț among patients receiving non-absorbable antibiotics for gut decop tamination. Br Med J 1981;283:408-9. 
16 Greenfield C, Szawathowski M, Noone P, Burroughs A, Bass N, Pounder R. Is pseudomembranous colitis infectious? Lancet $1981 ; i: 371-2$.

${ }^{17}$ Fekety R, Kim KH, Batts DH, et al. Studies on the epidemiology of antibiotic-associated Clostridium difficile colitis. Am J Clin Nutr 1980;33:2527-32.

${ }^{18}$ Larson HE, Borriello SP. Pseudomembranous colitis. In: Jewel DP, ed. Advanced medicine Vol 17, London: Pitman Medical, 1981:120-7.

19 Mulligan ME, George WL, Rolfe RD, Finegold SM. Epidemiological aspects of Clostridium difficile-induced diarrhoea and colitis. Am J Clin Nutr 1980;33:2533-8.

${ }^{20}$ Rampling A, Matthews IG. Routine experience with Clostridium difficile in Cambridge. Eur J Chemother Antibiot 1982;2:163-5.

${ }^{21}$ Miller RR, Jick H. Antibiotic-associated colitis. Clin Pharmacol Ther 1977;22:1-6.

22 Borriello SP, Honour P. Simplified procedure for the routine isolation of Clostridium difficile from faeces. J Clin Pathol 1981;34:1124-7.

${ }^{23}$ Raibaud P, Ducluzeau R, Dubos F, Hudault S, Bewa H, Muller MC, Implantation of bacteria from the digestive tract of man and various animals into gnotobiotic mice. Am J Clin Nutr 1980;33:2440-7.

${ }^{24}$ Borriello SP. An evaluated micromethod for the detection of Clostridium difficile enterotoxin. Microbios Lett 1979;7:25-8.
${ }^{25}$ Larson HE, Price AB, Borriello SP. Epidemiology of experimental enterocecitis due to Clostridium difficile. J Infect Dis 1980;142:40813.

${ }^{26}$ Hafiz SL. Clostridium difficile and its toxins, University of Leeds: $\mathrm{PhD}$ thesis, 1974.

${ }^{27}$ Princewell TJT, Agba MI. Examination of bovine faeces for the isolation and identification of Clostridium species.J Appl Bacteriol 1982;52:97-102.

${ }^{28}$ McBee RH. Intestinal flora of some antarctic birds and mammals. $J$ Bacteriol 1960;79:311-2.

29 Dabard J. Dubos F, Martinet L, Ducluzeau R. Experimental reproduction of neonatal diarhoea in young gnotobiotic hares simultaneously associated with Clostridium difficile and other Clostridium strains. Infect Immun. 1979;24:7-11.

${ }^{30}$ Bartlett JG, Tedesco FJ, Shull S, Lowe B, Chang TW. Symptomatic relapse after oral treatment of antibiotic associated colitis. Gastroenterology 1980;78:431-4.

Requests for reprints to: Dr SP Borriello, Clinical Research Centre, Watford Road, Harrow, Middlesex, HA1 3UJ, England. 